\title{
PENGARUH PENDAMPINGAN KELUARGA TERHADAP KECEMASAN BELAJAR ANAK PADA PEMBELAJARAN JARAK JAUH SELAMA PANDEMI COVID-19
}

\author{
Sandra Febby Eka Putri ${ }^{1 *}$, Zaenal Abidin², Karina Nur Ramadhanintyas ${ }^{3}$, \\ Riska Ratnawati ${ }^{4}$ \\ 1,2,3,4Sekolah Tinggi Ilmu Kesehatan Bhakti Husada Mulia Madiun, Indonesia. \\ E-mail: sandraekaputri88@gmail.com ${ }^{1}$ \\ E-mail: zapb17@gmail.com \\ E-mail: nr.karin4@gmail.com² \\ E-mail: riskaratnawati78@gmail.com ${ }^{3}$
}

DOI: https://doi.org/10.53754/edusia.v1i1.116

\begin{tabular}{l|l} 
Received: 2021-10-03 & Revised: 2021-10-17
\end{tabular}

Approved: 2021-10-19

\begin{abstract}
Learning anxiety is an excessive feeling of being afraid of threats or felt during distance learning. In overcoming children's anxiety, one of the assistance efforts made is family support. Family support is an act of assisting to meet the needs and problem solving of children in order to support the optimization of children's development. In this study, researchers used quantitative descriptive as an approach. The research method used is an analytic survey while the type of research is cross sectional. In analyzing the data, researchers used univariate as a measuring tool and the Chi-Square test as bivariate. The population of elementary school children in grades 4-6 is 60 respondents and the sample is 60 respondents. The results of the bivariate test showed that there was a significant relationship between the independent variables, that the $p$ value was $0.044(p<0.05)$, which means that there is an influence between family support and children's learning anxiety. In this study, the study analyzed that the Chi-Square test had 2 (two) most influential variables, namely family support and children's learning anxiety. The conclusion of this study is that there is a significant relationship between family support and children's learning anxiety. From this research, it is expected that children will learn with others so that children do not experience anxiety.
\end{abstract}

Keywords: Covid-19 distance learning; family assistance; learning anxiety

Abstrak: Kecemasan belajar merupakan perasaan yang berlebihan pada kondisi ketakutan terhadap ancaman atau yang dirasakan selama mengikuti pembelajaran jarak jauh. Dalam mengatasi kecemasan anak, upaya bantuan yang dilakukan salah satunya dukungan keluarga. Dukungan keluarga merupakan tindakan mendampingi untuk memenuhi kebutuhan dan pemecahan masalah anak dalam rangka mendukung optimalisasi perkembangan anak. Dalam penelitian ini, peneliti menggunakan deskriptif kuantitatif sebagai pendekatan. Metode penelitian yang digunakan adalah survei analitik sedangkan jenis penelitiannya adalah cross sectional. Dalam menganalisis data, peneliti menggunakan univariat sebagai alat ukur, uji Chi-Square sebagai bivariat. Populasi anak SD kelas 4-6 sebanyak 60 responden dan sampel sebanyak 60 responden. Hasil uji bivariat menunjukkan ada hubungan yang signifikan antara variabel bebas, bahwa nilai $p$ value $0,044(p<0,05)$ yang 
Pengaruh Pendampingan Keluarga Terhadap Kecemasan Belajar Anak pada Pembelajaran Jarak jauh Selama Pandemi Covid-19 di SDN 3 Duri Kabupaten Ponorogo artinya terdapat pengaruh antara dukungan keluarga dengan kecemasan belajar anak. Dalam penelitian ini, penelitian menganalisis bahwa uji Chi-Square memiliki 2 (dua) variabel yang paling berpengaruh, yaitu dukungan keluarga dan kecemasan belajar anak. Responden yang memiliki dukungan keluarga dengan tidak adanya kecemasan yang baik akan sangat mempengaruhi seseorang untuk memberikan dukungan belajarnya, Kesimpulan dalam penelitian ini adalah terdapat hubungan yang signifikan antara dukungan keluarga dengan kecemasan belajar anak. Dari penelitian ini saran yang diharapkan anak untuk belajar dengan orang lain agar anak tidak mengalami kecemasan.

Kata Kunci: Dukungan keluarga; Kecemasan belajar; Pembelajaran jarak jauh 
Pengaruh Pendampingan Keluarga Terhadap Kecemasan Belajar Anak pada Pembelajaran Jarak jauh Selama Pandemi Covid-19 di SDN 3 Duri Kabupaten Ponorogo

\section{PENDAHULUAN}

Begitu virus Corona masuk ke Indonesia pada awal Maret 2020. Pihak berwenang bertindak cepat untuk menghentikan penyebarannya lebih jauh. Salah satunya adalah sistem pembelajaran jarak jauh. Untuk mengadopsi pembelajaran jarak jauh, salah satu opsi adalah menawarkan pembelajaran di rumah kepada siswa kelas K hingga 12. Sehubungan dengan tahun ajaran 2020/2021 dan tahun ajaran 2020/2021 selama masa pandemi Corona Virus Disease 2019 (Covid-19). Kebijakan pembelajaran jarak jauh didasarkan pada Surat Keputusan Bersama (SKB) yang diterbitkan pada 7 Agustus 2020 oleh Empat Menteri. Pembelajaran tatap muka semula diperbolehkan hanya di zona hijau, namun diubah dengan SK Empat Menteri.

Sebagai konsekuensinya penentuan kebijakan pembelajaran tatap muka hanya dilakukan pada wilayah yang ditetapkan sebagai zona hijau dan zona kuning pandemi Covid-19. Adapun penetapan zona tersebut merupakan kewenangan penuh dari Pemerintah Daerah dan kantor atau Kanwil/Kemenag masing-masing daerah beserta pihak sekolah. Berdasarkan penentuan zona tersebut, pada bulan Januari 2021 yang lalu Provinsi Jawa Timur tercatat menjadi provinsi dengan laporan pasien meninggal tertinggi dan di provinsi tersebut juga terdapat tujuh daerah zona merah, yang salah satunya adalah Kabupaten Ponorogo. ${ }^{1}$ Angka kematian pasien Covid-19 di Kabupaten Ponorogo mencapai 5,29\% melebihi angka rata-rata nasional yang mencapai 3,12\%. Sementara untuk angka kesembuhan pasien kasus Covid-19 di Kabupaten Ponorogo 70\% atau masih di bawah rata-rata nasional yang mencapai $80 \%$. Kondisi itu menjadikan Kabupaten Ponorogo masuk sebagai daerah zona merah Covid-19. Zona merah menunjukkan bahwa risiko penularan kasus Covid-19 sangat cepat dan meluas dibandingkan zona-zona yang lain.

Penetapan Kabupaten Ponorogo sebagai zona merah Covid-19 berdampak pada pelaksanaan pembelajaran di sekolah. Berdasarkan SKB Empat Menteri tanggal 7 Agustus 2020. Pemerintah Kabupaten Ponorogo mengeluarkan kebijakan pembelajaran untuk siswa dilakukan secara jarak jauh dari rumah atau secara daring. Hal ini juga didukung dari informasi yang diperoleh dari Dinas Pendidikan (Dindik) Kabupaten Ponorogo kembali menerapkan pembelajaran jarak jauh (PJJ) kepada 9 SMP dan 42 SD di daerah tersebut. Kebijakan belajar di rumah ini dilakukan untuk mengurangi interaksi fisik sebagai upaya pencegahan penularan virus Covid-19. ${ }^{2}$

Berdasarkan temuan awal dari sebuah penelitian terhadap anak-anak di Desa Duri, Kecamatan Slahung, Kabupaten Ponorogo, beban belajar yang diberikan guru membuat anak-anak cemas tentang pembelajaran jarak jauh. Banyak tugas yang diberikan oleh guru dan memiliki waktu pemrosesan yang singkat, yang

\footnotetext{
${ }^{1}$ Kompas, "Ponorogo Zona Merah Covid-19, Angka Kematian Di Atas Rata-Rata Nasional," kompas.com, 2021, https://regional.kompas.com/read/2021/01/19/21172411/ponorogo-zona-merah-covid-19-angkakematian-di-atas-rata-rata-nasional?page=all.

2 Mufadhal Barseli, Ifdil Ifdil, and Linda Fitria, "Stress Akademik Akibat Covid-19," Jurnal Penelitian Guru Indonesia 5, no. 2 (2020).
} 
Pengaruh Pendampingan Keluarga Terhadap Kecemasan Belajar Anak pada Pembelajaran Jarak jauh Selama Pandemi Covid-19 di SDN 3 Duri Kabupaten Ponorogo

membingungkan siswa. Dengan begitu banyak tugas, anak-anak mungkin menghabiskan sepanjang hari melakukan aktivitas daring. Karena itu banyak siswa yang mengeluhkan ketegangan atau kecemasan.

Kecemasan adalah suatu keadaan psikologis yang ditandai dengan berkembangnya rasa tidak nyaman pada diri seseorang. Ini adalah sensasi kabur disertai dengan emosi ketidakberdayaan dan ketidakpastian yang dipicu oleh apa pun yang tidak didefinisikan dengan jelas. ${ }^{3}$ Kecemasan adalah bagian alami dari kehidupan sehari-hari karena diperlukan sebagai indikasi peringatan bahaya yang akan datang. Kecemasan di sisi lain dapat mengganggu tugas sehari-hari jika itu terjadi secara konsisten dan tidak masuk akal, dan tingkat keparahannya meningkat setiap hari.

Menurut Survei Kesehatan Nasional (SUSENAS) 2010, jumlah anak dengan kecemasan di wilayah metropolitan Indonesia adalah 25,8 persen untuk anak usia 04 tahun, 14,91 persen untuk anak usia 5-12 tahun, 9,1 persen untuk anak usia 13-15 tahun. tahun, dan 8,13 persen untuk anak usia 16-21 tahun. ${ }^{4}$ Menghitung tingkat kecemasan anak usia 0-21 tahun dari seluruh populasi menghasilkan angka 14,44, yang berpotensi berdampak negatif pada kesejahteraan fisik dan psikologis remaja. ${ }^{5}$ Organisasi Kesehatan Dunia WHO mengatakan bahwa kesedihan dan kecemasan adalah penyakit mental yang paling umum. Kecemasan mempengaruhi sekitar 200 juta orang (3,6\% dari populasi). Sementara itu, 322 juta orang menderita depresi secara global (4,4 persen dari populasi), dengan hampir setengahnya berasal dari Asia Tenggara dan Pasifik Barat. Depresi berkontribusi pada sekitar 800.000 kasus bunuh diri setiap tahun. ${ }^{6}$ Di Indonesia, prevalensi terkait gangguan kecemasan pada penduduk umur $\geq 15$ tahun menurut Riset Kesehatan Dasar (Riskesdas) pada tahun 2018 adalah sebesar 6,1\% dengan prevalensi depresi dan kecemasan untuk provinsi Jawa Timur adalah sebesar 4,5\%.7 Adapun prevalensi depresi dan kecemasan untuk kelompok umur 15 tahun ke atas di Kabupaten Ponorogo adalah 1,53\%. Angka ini termasuk rendah dibandingkan daerah lain dan dibandingkan prevalensi rata-rata depresi dan kecemasan untuk Provinsi Jawa Timur yang sebesar 4,53\%. ${ }^{8}$

\footnotetext{
${ }^{3}$ Nidya Puspita Rachman Dwi Sari, "Perbedaan Tingkat Kecemasan Masa Depan Karir Anak Ditinjau Dari Selfconcept Dan Persepsi Dukungan Sosial Pada Ibu Anak Tunarungu Di Smalb-B Karya Mulia Surabaya," Character: Jurnal Penelitian Psikologi. 2, no. 1 (2013).

4 Badan Pusat Statistik, "Survei Sosial Ekonomi Nasional (SUSENAS) Kor, 2010," BPS, 2010, https:/ / sirusa.bps.go.id/sirusa/index.php/dasar/view?kd=1558\&th=2010.

${ }^{5}$ Dyna Apriany, "Hubungan Antara Hospitalisasi Anak Dengan Tingkat Kecemasan Orang Tua," Jurnal Keperawatan Soedirman Vol. 8, no. No. 2 (2013).

${ }^{6}$ Biro Komunikasi dan Pelayanan Masyarakat, "Peran Keluarga Dukung Kesehatan Jiwa Masyarakat," Kementerian Kesehatan RI, 2016, https://www.kemkes.go.id/article/print/16100700005/peran-keluargadukung-kesehatan-jiwa-masyarakat.html.

7 Badan Penelitian dan Pengembangan Kesehatan, "Laporan Hasil Riset Kesehatan Dasar (Riskesdas)," Badan Penelitian dan Pengembangan Kesehatan, 2018, https://www.litbang.kemkes.go.id/laporan-risetkesehatan-dasar-riskesdas/.

8 Badan Penelitian dan Pengembangan Kesehatan.
} 
Adanya kecemasan yang terjadi pada anak-anak di Desa Duri Kecamatan Slahung Kabupaten Ponorogo selama pelaksanaan pembelajaran jarak jauh perlu disikapi dengan bijak. Salah satunya adalah melalui pendampingan oleh keluarga selama anak mengikuti pembelajaran jarak jauh. Menurut penelitian yang dilakukan Anggraeni et.al, dalam pembelajaran jarak jauh peran orang tua juga sangat diperlukan. ${ }^{9}$ Adapun peran orang tua dalam pembelajaran jarak jauh yaitu, memiliki peran sebagai guru di rumah, sebagai fasilitator, sebagai motivator dan sebagai director.

Pembelajaran jarak jauh memungkinkan semua anggota keluarga menjadi instruktur di rumah, membimbing anak-anak dalam belajar dari jarak jauh. Anggota keluarga juga harus mendidik anak-anak muda yang tidak memahami pandemi endemik untuk tetap di rumah dan tidak terinfeksi dan menyebarkan wabah pandemi. ${ }^{10}$ Pada penelitian yang dilakukan Fauziyah et.al, ${ }^{11}$ terbukti pendampingan orang tua berpengaruh signifikan terhadap kecerdasan emosional anak yang mengikuti pembelajaran daring. Anak yang memiliki kecerdasan emosional akan mampu mengelola emosi dengan baik sehingga memiliki kemampuan untuk mengatasi stress dan dapat mengurangi perasaan cemas dalam mengikuti pembelajaran jarak jauh.

Peran anggota keluarga dalam situasi pandemi Covid-19 ini memiliki kedudukan yang fundamental. Hasil observasi awal pada anak-anak di Desa Duri Kecamatan Slahung Kabupaten Ponorogo yang mengikuti pembelajaran jarak jauh selama pandemi Covid-19 menunjukkan bahwa tidak semuanya mendapat pendampingan yang memadai dari orang tua dan anggota keluarga yang lain karena banyak juga para orang tua yang harus bekerja di sawah dan malam harinya sudah capek sehingga tidak memiliki waktu yang cukup untuk mendampingi anakanaknya.

Berkaitan dengan adanya kecemasan yang dapat terjadi pada anak yang mengikuti pembelajaran jarak jauh selama Pandemi Covid-19 serta perlunya peran keluarga dalam mendampingi anak-anak selama belajar, maka perlu dilakukan analisis sejauh mana tingkat kecemasan belajar yang terjadi pada anak, bentuk-bentuk pendampingan yang dilakukan keluarga terhadap anak-anak selama belajar secara daring, serta dampak pendampingan yang dilakukan keluarga terhadap tingkat kecemasan pada anak. Keberhasilan upaya pendampingan yang dilakukan keluarga terhadap anak yang mengikuti pembelajaran jarak jauh secara daring juga perlu dibuktikan melalui penelitian. Alasan memilih lokasi penelitian ini karena jumlah siswa terbanyak di kelas 4-6 bertempat di SDN 3 Duri. Oleh karena itu, peneliti

\footnotetext{
${ }_{9}^{9}$ Ria Nur Anggraeni, Fina Fakhriyah, and Muhammad Noor Ahsin, "Peran Orang Tua Sebagai Fasilitator Anak Dalam Proses Pembelajaran Online Di Rumah," Jurnal Ilmiah Pendidikan Dasar 8, no. 2 (July 30, 2021): 105, https://doi.org/10.30659/pendas.8.2.105-117.

10 Ghesya Athira Hasna'ul Fauzyah, Luthfi Hamdani Maula, and Iis Nurasiah, "Pengaruh Pendampingan Orang Tua Pada Pembelajaran Daring Terhadap Kecerdasan Emosional," Jurnal Pendidikan Dasar, 2020.

11 Fauzyah, Maula, and Nurasiah.
} 
Pengaruh Pendampingan Keluarga Terhadap Kecemasan Belajar Anak pada Pembelajaran Jarak jauh Selama Pandemi Covid-19 di SDN 3 Duri Kabupaten Ponorogo

tertarik untuk mengadakan penelitian tentang "Pengaruh Pendampingan Keluarga terhadap Kecemasan Belajar Anak Pada Pembelajaran Jarak Jauh Selama Pandemi Covid-19 di SDN 3 Duri Slahung Ponorogo."

Dalam penelitian ini menggunakan deskriptif kuantitatif sebagai pendekatannya. Metode penelitian yang digunakan adalah survei analitik sedangkan jenis penelitiannya adalah cross-sectional. Dalam menganalisis data, peneliti menggunakan univariat sebagai alat ukur, uji Chi-Square sebagai bivariat. Populasi anak SD kelas 4-6 sebanyak 60 responden dan sampel sebanyak 60 responden.

Dalam penelitian ini, peneliti berperan sebagai alat dalam pengumpulan data, meskipun dibantu oleh alat pengumpulan data, pengumpulan data dilakukan oleh peneliti sendiri.12 Alat yang digunakan dalam pengumpulan data adalah kuesioner. Kuesioner bertujuan untuk memperoleh informasi tertentu dari semua partisipan, dan susunan kata serta urutannya selalu mengikuti daftar pertanyaan yang telah dibuat. Sebelum pengambilan data, peneliti melakukan uji validitas dengan melakukan wawancara kepada 10 orang dengan pertanyaan yang telah dibuat oleh peneliti. Hasil uji validitas menunjukkan bahwa angket layak untuk dipahami oleh responden dan semua pertanyaan yang diajukan peneliti.

Hipotesis penelitian ini adalah:

H1: Ada pengaruh pendampingan keluarga terhadap kecemasan belajar anak pada pembelajaran jarak jauh selama pandemi Covid-19 di SDN 3 Duri Slahung Ponorogo.

Ho: Tidak ada pengaruh pendampingan keluarga terhadap kecemasan belajar anak pada pembelajaran jarak jauh selama pandemi Covid-19 di SDN 3 Duri Slahung Ponorogo.

Penelitian ini menggambarkan bahwa yang akan diteliti adalah pengaruh pendampingan keluarga terhadap kecemasan belajar anak pada pembelajaran jarak jauh selama pandemi Covid-19. Kerangka konseptual penelitian ini tercantum pada gambar berikut;

12 John W. Creswell and J. David Creswell, "Research Design: Qualitative, Quantitative, and Mixed Methods Approaches - John W. Creswell, J. David Creswell - Google Books," SAGE Publications, Inc., 2018. 
Pengaruh Pendampingan Keluarga Terhadap Kecemasan Belajar Anak pada Pembelajaran Jarak jauh Selama Pandemi Covid-19 di SDN 3 Duri Kabupaten Ponorogo

Gambar 1. Kerangka Konseptual Penelitian

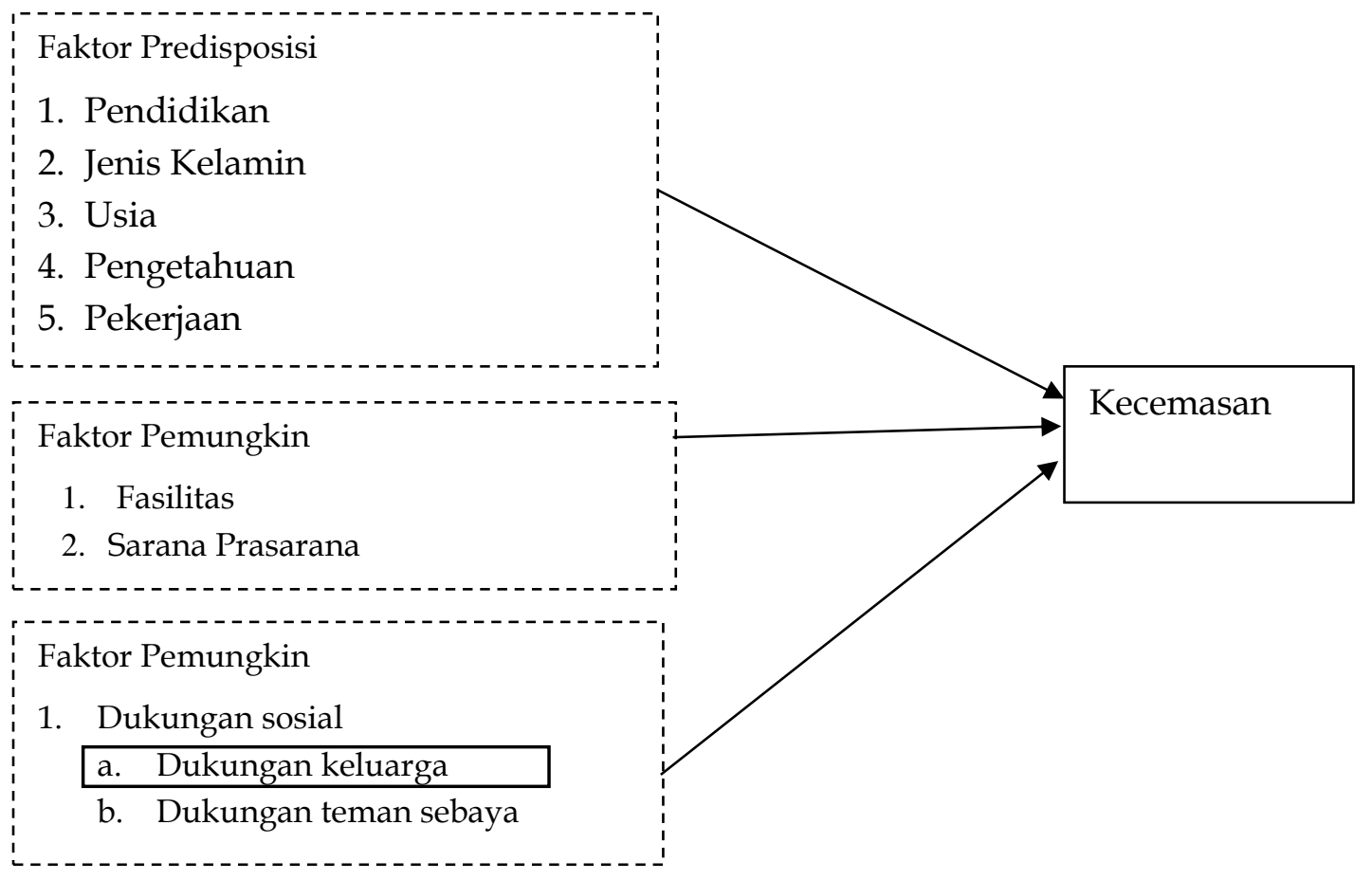


Pengaruh Pendampingan Keluarga Terhadap Kecemasan Belajar Anak pada Pembelajaran Jarak jauh Selama Pandemi Covid-19 di SDN 3 Duri Kabupaten Ponorogo

Gambar 2. Kerangka kerja penelitian

Populasi Target: Anak kelas 4-6 di SDN 3 Duri Slahung Kabupaten Ponorogo yang mengikuti pembelajaran jarak jauh dan mendapat pendampingan oleh keluarga yang berjumlah 60 orang

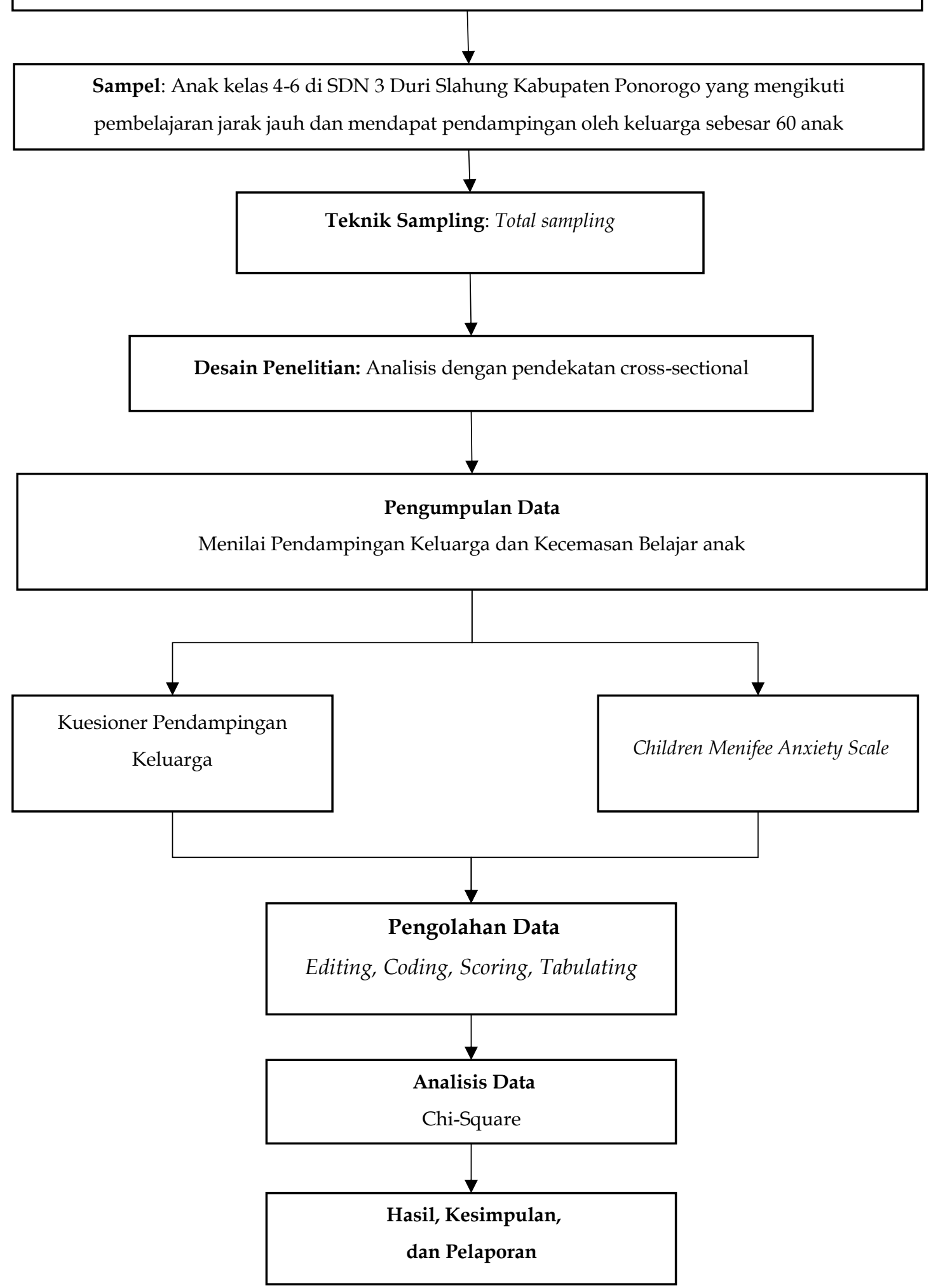




\section{PEMBAHASAN}

\subsection{Analisis Univariat}

\subsubsection{Distribusi Frekuensi Responden Berdasarkan Usia Keluarga dan Usia Anak}

Dari kuesioner yang telah disebarkan peneliti kepada responden, maka diperoleh karakteristik responden yaitu karakteristik usia, pendidikan dan jenis kelamin. Karakteristik responden dalam pendampingan keluarga terhadap kecemasan belajar anak dapat dilihat sebagai berikut:

Tabel 1 Distribusi Frekuensi Responden Berdasarkan Usia Keluarga

\begin{tabular}{llll}
\hline No & Usia (tahun) & Frekuensi & $\%$ \\
\hline 1 & Dewasa awal (26-35 tahun) & 1 & 1,9 \\
\hline 2 & Dewasa akhir (36-45 tahun) & 36 & 67,9 \\
\hline 3 & Lansia Awal (46-55 Tahun) & 16 & 30,2 \\
\hline Jumlah & 53 & $100 \%$ \\
\hline Jumlah & 53 & $100 \%$ \\
\hline
\end{tabular}

Berdasarkan tabel 1 di atas dapat dilihat bahwa sebagian besar keluarga yang mendampingi belajar anak selama pandemi diketahui yang berusia 36-45 sebanyak 36 responden dengan prosentase $(67,9 \%)$, dan untuk usia atau berumur 26-35 terdapat 1 responden dengan prosentase $(1,9 \%)$.

Tabel 2 Distribusi Frekuensi Responden Berdasarkan Usia Anak

\begin{tabular}{llll}
\hline No & Usia (tahun) & Frekuensi & $\%$ \\
\hline 1 & $8-9$ tahun & 18 & 34,0 \\
2 & $10-12$ tahun & 35 & 66,0 \\
\hline Jumlah & 53 & $100 \%$ \\
\hline
\end{tabular}

Berdasarkan tabel 2 diatas dapat dilihat bahwa sebagian besar yang berusia 1012 tahun sebanyak 35 responden dengan presentase $(66,0 \%)$ yang mengikuti pembelajaran jarak jauh kelas 4-6 pada saat pandemi di SDN 3 duri Kabupaten Ponorogo.

\subsubsection{Distribusi Frekuensi Responden Berdasarkan Tingkat Pendidikan}

Berdasarkan penelitian yang sudah dilaksanakan oleh peneliti mendapatkan analisis tingkat pendidikan terakhir responden, dapat di lihat pada tabel berikut ini :

Tabel 3 Distribusi Frekuensi Responden Berdasarkan Pendidikan

\begin{tabular}{llll}
\hline No & Jenjang Pendidikan & Frekuensi & $\%$ \\
\hline 1 & SD & 32 & 60,4 \\
2 & SMP & 21 & 39,6 \\
\hline Jumlah & 53 & $100 \%$ \\
\hline
\end{tabular}


Berdasarkan tabel 3 di atas menunjukkan bahwa keluarga yang mendampingi belajar anak selama pandemi sebagian besar berpendidikan SD sebanyak 32 responden dengan presentase $(60,4 \%)$. Berdasarkan tabel tersebut, dapat dikatakan golongan pendidikan orang tua yang mendampingi anak-anaknya dapat dikatakan masih rendah. Hal ini berdampak pada pendampingan belajar diantaranya, orang tua kesulitan menumbuhkan minat dan motivasi belajar, kurangnya pemahaman dan penyampaian materi dan kurangnya pemahaman pengoperasian guna pendukung pembelajaran.

\subsubsection{Distribusi Frekuensi Responden Berdasarkan Jenis Kelamin}

Responden Berdasarkan penelitian yang sudah dilaksanakan oleh peneliti mendapatkan analisis jenis kelamin responden, dapat dilihat pada tabel berikut ini :

Tabel 4 Distribusi Frekuensi Responden Berdasarkan jenis Kelamin

\begin{tabular}{llll}
\hline No & Jenis Kelamin & Frekuensi & $\%$ \\
\hline 1 & Laki-laki & 21 & 39,6 \\
2 & Perempuan & 32 & 60,4 \\
\hline Jumlah & 53 & $100 \%$ & \\
\hline
\end{tabular}

Berdasarkan tabel 4 di atas menunjukkan bahwa jenis kelamin anak kelas 4-6 yang mengikuti pembelajaran jarak jauh selama pandemi sebagian besar di SDN 3 Duri Kabupaten Ponorogo yang terbanyak berjenis kelamin perempuan menunjukkan angka sebanyak 32 responden dengan prosentase $(60,4 \%)$.

\subsubsection{Distribusi Frekuensi Responden Berdasarkan Dukungan Keluarga}

Tabel 5 Distribusi Frekuensi Variabel Dukungan Keluarga

\begin{tabular}{llll}
\hline No & $\begin{array}{l}\text { Variabel } \\
\text { Dukungan } \\
\text { Keluarga }\end{array}$ & Frekuensi (N) & Presentasi (\%) \\
\hline 1 & Tidak Mendukung & 29 & 54,7 \\
2 & Mendukung & 24 & 45,3 \\
\multicolumn{2}{l}{ Total } & 53 & 100 \\
\hline
\end{tabular}

Berdasarkan tabel 5 distribusi di atas maka dapat dikatakan bahwa dukungan keluarga terhadap kecemasan belajar anak adalah 29 (54,7\%) sedangkan dukungan keluarga yang tidak mendukung berjumlah $24(45,3 \%)$.

\subsubsection{Distribusi Frekuensi Kecemasan Belajar Anak}

Tabel 6 Distribusi Frekuensi Variabel Kecemasan Belajar Anak

\begin{tabular}{llll}
\hline No & Variabel Kecemasan & $\begin{array}{l}\text { Frekuensi } \\
(\mathrm{N})\end{array}$ & $\begin{array}{l}\text { Presentasi } \\
(\%)\end{array}$ \\
\hline
\end{tabular}


Pengaruh Pendampingan Keluarga Terhadap Kecemasan Belajar Anak pada Pembelajaran Jarak jauh Selama Pandemi Covid-19 di SDN 3 Duri Kabupaten Ponorogo

\begin{tabular}{lll}
\hline $1 \quad$ Cemas & 24 & 45,3 \\
$2 \quad$ Tidak Cemas & 29 & 54,7 \\
Total & 53 & 100 \\
\hline
\end{tabular}

Berdasarkan tabel distribusi frekuensi di atas variabel kecemasan belajar terdapat ada kecemasan sebanyak 24 siswa dengan presentase $(45,3 \%)$. Sedangkan yang siswa yang tidak mengalami kecemasan terdapat sebanyak 29 siswa dengan presentase $(54,7 \%)$.

\subsection{Analisis Bivariat}

Salah satu metode untuk menentukan hubungan antara variabel independen dan dependen adalah melalui analisis bivariat. Pada penelitian ini hubungan dukungan keluarga terhadap kecemasan belajar anak selama pandemi covid-19, dengan membuktikan hipotesis dengan cara menguji menggunakan program SPSS. Pada penelitian ini peneliti menguji hipotesis dengan Chi-Square dengan menggunkan sig 0,05 yang artinya < 0,05 H1 di tolak, sedangkan jika > 0,05 maka H1 diterima karena menunjukkan adanya hubungan yang signifikan. Berikut adalah hasil dari uji bivariat dukungan keluarga terhadap kecemasan belajar anak di SDN 3 Duri Kabupaten Ponorogo.

Berdasarkan analisis bivariat pengaruh dukungan keluarga terhadap kecemasan belajar anak pada pembelajaran jarak jauh selama Pandemi Covid-19 di SDN 3 Duri Kabupaten Ponorogo adalah sebagaimana paparan pada tabel 7 berikut:

Tabel 7 Pengaruh Dukungan keluarga terhadap kecemasan belajar anak di SDN 3 Duri Kabupaten Ponorogo.

\begin{tabular}{|c|c|c|c|c|c|c|c|c|c|}
\hline \multirow{4}{*}{ No. } & \multirow{4}{*}{$\begin{array}{l}\text { Dukungan } \\
\text { Keluarga }\end{array}$} & \multicolumn{3}{|c|}{ Kecemasan } & \multicolumn{3}{|c|}{ BelajarTotal } & \multirow[t]{4}{*}{$95 \% \mathrm{CI}$} & \multirow[t]{4}{*}{ PR } \\
\hline & & An & & & & & & & \\
\hline & & \multicolumn{2}{|c|}{ Cemas } & \multicolumn{4}{|c|}{ Tidak Cemas } & & \\
\hline & & $\mathbf{N}$ & $\%$ & $\mathbf{N}$ & $\%$ & $\mathbf{N}$ & $\%$ & & \\
\hline \multirow[t]{2}{*}{1.} & Tidak & 9 & 13,1 & 20 & 15,9 & 29 & 100,0 & \multirow[t]{4}{*}{$0,086-0,8450,044$} & \multirow[t]{4}{*}{0,270} \\
\hline & Mendukung & & & & & & & & \\
\hline \multirow[t]{2}{*}{2.} & Mendukung & g15 & 10,9 & 9 & 13,1 & 24 & 100,0 & & \\
\hline & Total & 24 & 23,5 & 29 & 28,9 & 53 & 100,0 & & \\
\hline
\end{tabular}

Berdasarkan tabel 7 analisis Pengaruh Dukungan Keluarga terhadap kecemasan belajar anak pada pembelajaran jarak jauh selama pandemi Covid-19 di SDN 3 Duri Kabupaten Ponorogo yang di olah peneliti dengan menggunakan uji chisquare dan didapatkan hasil dari variabel dukungan keluarga yang tidak mendukung terhadap kecamasan belajar anak diketahui dengan adanya kecemasan sebanyak 9 responden dengan presentase $13,1 \%$. Dukungan keluarga yang tidak mendukung terhadap kecemasan belajar anak dengan tidak cemas sebanyak 20 responden dengan presentase $15,9 \%$. Dukungan keluarga yang mendukung terhadap kecemasan belajar 
anak dengan adanya kecemasan sebanyak 15 responden dengan presentase 10,9\%. Dukungan keluarga yang mendukung terhadap kecemasan belajar anak dengan tidak ada kecemasan sebanyak 9 dengan presentase $13,1 \%$.

Berdasarkan hasil pengelolaan data primer peneliti dilakukan dengan uji chisquare menunjukkan bahwa nilai $\mathrm{p}$ value $0,044(\mathrm{p}<0,05)$ yang artinya $\mathrm{H} 0$ ditolak dan H1 diterima karena ada pengaruh antara dukungan keluarga dengan kecemasan belajar anak pada masa pendemi covid-19 di SDN 3 Duri Kabupaten Ponorogo.

\subsection{Pengaruh Dukungan Keluarga terhadap Kecemasan Belajar Anak pada Pembelajaran Jarak Jauh selama Pandemi Covid-19 Kabupaten Ponorogo}

Berdasarkan hasil analisis univariate jumlah distribusi frekuensi variable dukungan keluarga yang tidak mendukung belajar anak pada masa pandemi Covid19 di SDN 3 Duri Kabupaten Ponorogo sebanyak 29 responden dengan presentasi sebesar $54,7 \%$ dan untuk dukungan keluarga yang mendukung belajar anak sebesar 24 responden dengan presentasi $45,3 \%$.

Berdasarkan hasil analisis bivariate dengan menggunakan uji statistik dengan menggunakan uji chi-square dengan tujuan untuk mengetahui apakah ada hubungan antara variable dukungan keluarga dengan kecemasan belajar anak pada pembelajaran jarak jauh selama pandemi Covid-19 di SDN 3 Duri Kabupaten Ponorogo yang memiliki dukungan keluarga yang tidak mendukung terhadap kecemasan belajar anak diketahui adanya kecemasan sebanyak 9 responden dengan presentase $13,1 \%$,dukungan keluarga yang tidak mendukung terhadap kecemasan belajar anak dengan tidak cemas sebanyak 20 responden dengan presentase $15,9 \%$, dukungan keluarga yang mendukung terhadap kecemasan belajar anak dengan adanya kecemasan sebanyak 15 responden dengan presentase 10,9\%, dukungan keluarga yang mendukung terhadap kecemasan belajar anak dengan tidak ada kecemasan sebanyak 9 dengan presentase $13,1 \%$.

Hal ini menunjukkan faktor dukungan keluarga berpengaruh terhadap kecemasan belajar anak pada pembelajaran jarak jauh selama pandemi Covid-19. Maka dapat dilihat dengan di peroleh nilai $\mathrm{p}(0,044)<\alpha(0,05)$ yang dapat dikatakan bahwa ada pengaruh yang signifikan antara variabel dukungan keluarga dengan kecemasan belajar anak pada pembelajaran jarak jauh selama pandemi Covid-19 di SDN 3 Duri Kabupaten Ponorogo.

Adanya Pengaruh dukungan keluarga dengan kecemasan belajar anak pada pembelajaran jarak jauh selama pandemi Covid-19 sesuai dengan teori Friedman ${ }^{13}$ bahwa dukungan keluarga meliputi bantuan informasional, evaluasi, instrumental, dan emosional. Jadi dukungan keluarga adalah hubungan interpersonal yang

${ }^{13}$ Andreas Maercker and Axel Perkonigg, "Applying an International Perspective in Defining PTSD and Related Disorders: Comment on Friedman (2013)," Journal of Traumatic Stress, 2013, https://doi.org/10.1002/jts.21852. 
Pengaruh Pendampingan Keluarga Terhadap Kecemasan Belajar Anak pada Pembelajaran Jarak jauh Selama Pandemi Covid-19 di SDN 3 Duri Kabupaten Ponorogo

melibatkan sikap, perilaku, dan penerimaan anggota keluarga, sehingga mereka merasa terlihat. Dukungan keluarga diyakini dapat mengurangi atau menyangga dampak kesehatan mental individu. Hal ini sejalan dengan hasil penelitian Nahdi et al.,. ${ }^{14}$ Pendapat ini sejalan dengan pendapat Sekretaris Jenderal Federasi Serikat Guru Indonesia, bahwa dalam pembelajaran jarak jauh sampai saat ini, efektif dalam mengerjakan penugasan. ${ }^{15}$ Akan tetapi, dalam pembelajaran untuk memahami konsep, kemudian mengembangkan konsep itu sampai refleksi, tidak berjalan dengan sebaik itu. Maka dengan hal itu dukungan keluarga sangatlah penting untuk menumbuhkan semangat selama anak melakukan pembelajaran jarak jauh.

Hal ini sesuai dengan pendapat Purwanto et al.,16 dan Fauziah ${ }^{17}$ bahwa untuk melakukan pembelajaran online berbulan-bulan tentunya dibutuhkan kuota yang lebih banyak dan otomatis akan menambah biaya pembelian kuota internet. Banyak orang tua yang menganggap tugas guru terlalu banyak dan berat, namun kebanyakan orang tua senang karena tugas tersebut dianggap dapat membantu anak memahami lebih banyak informasi karena soal latihan yang diberikan.

Senada dengan Kurniati, Alfaeni, \& Andriani18 sebagaimana didukung oleh Jaenudin 19 bahwa orang tua dapat membimbing anak-anak mereka dengan membantu, mengarahkan, dan bahkan menawarkan pengalaman belajar yang lebih dalam terkait dengan kegiatan yang ditugaskan. Jadi, dalam pembelajaran jarak jauh, instruktur bertanggung jawab untuk memantau proses pembelajaran di rumah dan menilai aktivitas pembelajaran online.

Hal ini menunjukkan bahwa orang tua adalah madrasah pertama anaknya sebelum sekolah. Strategi pemerintah dalam pembelajaran online menyadarkan kita semua akan pentingnya mempelajari teknologi dan memanfaatkan teknologi secara positif. Ini juga bisa menjadi pelajaran penting bagi pendidikan Indonesia masa depan untuk mengatasi kesulitan saat ini.

Berdasarkan analisis yang telah dijelaskan di atas maka peneliti menyimpulkan faktanya di lapangan. Didapatkan kenyataan bahwa saat orang tua benar-banar memahami bahwa pendidikan anak merupakan tanggung jawab bersama, orang tua akan benar-banar aktif berpartisipasi mendampingi anaknya

14 Nurhasanah, "Peran Orang Tua Dalam Pembelajaran Daring Di Masa Pandemi Covid 19 Pada Kelompok B.5 TK Kemala Bhayangkari Bone," Educhild 2, no. 2 (2020).

15 Muhammad Ashari, "Proses Pembejalaran Daring Di Tengah Antisipasi Penyebaran Virus Corona Dinilai Belum Maksimal," pikiran-rakyat.com, 2020, https://www.pikiran-rakyat.com/pendidikan/pr01353818/proses-pembejalaran-daring-di-tengah-antisipasi-penyebaran-virus-corona-dinilai-belum-maksimal.

16 Agus Purwanto et al., "Studi Eksploratif Dampak Pandemi COVID-19 Terhadap Proses Pembelajaran Online Di Sekolah Dasar," EduPsyCouns: Journal of Education, Psychology and Counseling 2, no. 1 (2020).

17 Siti Zakiyatul Lutfiah, "Persepsi Orang Tua Mengenai Pembelajaran Online Di Rumah Selama Pandemi Covid-19," Dealektik 2, no. 2 (2020).

${ }^{18}$ Euis Kurniati et al., “Jurnal Obsesi : Jurnal Pendidikan Anak Usia Dini Analisis Peran Orang Tua Dalam Mendampingi Anak Di Masa Pandemi Covid-19," Jurnal Pendidikan Anak Usia Dini 5, no. 1 (2020): 241-56, https://obsesi.or.id/index.php/obsesi/article/view/541.

${ }_{19}$ Ahmad Jaenudin, “Literasi Digital Sebagai Solusi Guru Dalam Pembelajaran Era Digital Dan Pandemi Covid-19," Economic Education Analysis Journal 10, no. 1 (2021). 
dalam pembelajaran Jarak jauh. Namun kendalanya tidak semua orang tua dapat mendampingi anak saat pembelajaran daring dengan beberapa alasan, misalnya kesibukan orang tua bekerja. Hal inilah yang membuat pembelajaran jarak jauh belum diterima di masyarakat. Di lain hal, orang tua dengan latar belakang pendidikan yang rendah rata-rata mengalami kesulitan dalam mendampingi anak-anaknya ketika melakukan pembelajaran jarak jauh. Orang tua yang mendampingi anaknya terkadang kurang sabar dan jenuh menangani kemampuan dan konsentrasi anak yang duduk di bangku SD. Selain, itu orang tua yang tidak mendukung pembelajaran jarak jauh, mengalami kesulitan dalam menjelaskan materi pembelajaran anakanaknya. Sehingga terkadang menghambat proses belajar dan penyerapan materi pembelajaran anaknya. Melihat berbagai kondisi dan kendala yang orang tua alami dalam mendampingi pembelajaran anaknya, besar kiranya orang tua mengharapkan diadakannya pembelajaran tatap muka dengan menerapkan berbagai protokol kesehatan sesuai yang ditentukan, keinginan tersebut didasari akan keadaan orang tua sendiri yang rendah dalam pendidikan sehingga ditakutkan akan mempengaruhi dalam penyerapan dan pemahaman materi yang anak-anak mereka dapatkan. Ratarata orang tua hanya mampu mengupayakan memberikan fasilitas penunjang belajar dalam mendukung anak-anaknya dalam pembelajaran jarak jauh, namun dukungan fasilitas tersebut belum tentu sejalan dengan dukungan orang tua dalam mendampingi dan mengarahkan anak-anaknya dalam memahami pembelajaran anaknya. Harapan peneliti melihat kondisi tersebut, dibuatnya sistem kelompok belajar tertentu dalam lingkup sosial anak-anak pada suatu kelompok daerah yang bisa terdiri dari 5-6 kelompok anak dan dilakukan pendampingan dengan melakukan kunjungan rumah oleh guru pengajar, ini diharapkan agar kualitas belajar dan kemampuan penyerapan materi anak dapat dipantau dan diukur agar dapat sesuai dengan harapan capaian kurikulum pembelajaran sekolah dan bisa juga orang tua pun menyarankan anak tetap masuk sekolah dalam keadaan pandemi seperti ini dengan adanya shift sehingga anak bisa sekolah dengan fokus dan menerima pelajaran dengan baik di sekolah. Karena dengan adanya pembelajaran jarak jauh jika ada PR orang tua tidak bisa membantu mengerjakan tugas anak karena dari segi pendidikan orang tua dan kesibukan orang tua di rumah tersebut. Dari total sampel yang di ambil dari sejumlah 60 responden hanya 53 yang bersedia menjadi responden sedangkan yang lainnya orang tua tidak bersedia untuk diwawancarai dikarenakan kesibukan di rumahnya, dan waktu survey ada juga orang tua tidak ada di rumah. 


\section{KESIMPULAN}

Berdasarkan hasil penelitian yang dilakukan oleh peneliti "Pengaruh dukungan keluarga terhadap kecemasan belajar anak pada pembelajaran jarak jauh selama Pandemi Covid-19 di SDN 3 Duri Kabupaten Ponorogo" dapat diambil kesimpulan sebagai berikut ini: sebagian besar tidak mendampingi anak saat mengikuti pembelajaran jarak jauh selama Pandemi Covid-19 di Desa Duri Kabupaten Ponorogo (54,7\%). Sebagian kecil anak cemas saat mengikuti pembelajaran jarak jauh selama Pandemi Covid-19 di Desa Duri Kabupaten Ponorogo $(45,3 \%)$. Ada pengaruh antara variabel pendampingan keluarga dengan kecemasan belajar anak di SDN 3 Duri Slahung Kabupaten Ponorogo diketahui nilai p-value $(0,044)$.

\section{REFERENSI}

Anggraeni, Ria Nur, Fina Fakhriyah, and Muhammad Noor Ahsin. "Peran Orang Tua Sebagai Fasilitator Anak Dalam Proses Pembelajaran Online Di Rumah.” Jurnal Ilmiah Pendidikan Dasar 8, no. 2 (July 30, 2021): 105. https://doi.org/10.30659/pendas.8.2.105-117.

Apriany, Dyna. "Hubungan Antara Hospitalisasi Anak Dengan Tingkat Kecemasan Orang Tua." Jurnal Keperawatan Soedirman Vol. 8, no. No. 2 (2013).

Ashari, Muhammad. "Proses Pembejalaran Daring Di Tengah Antisipasi Penyebaran Virus Corona Dinilai Belum Maksimal." pikiran-rakyat.com, 2020. https:/ / www.pikiran-rakyat.com/pendidikan/pr-01353818/prosespembejalaran-daring-di-tengah-antisipasi-penyebaran-virus-corona-dinilaibelum-maksimal.

Badan Penelitian dan Pengembangan Kesehatan. "Laporan Hasil Riset Kesehatan Dasar (Riskesdas)." Badan Penelitian dan Pengembangan Kesehatan, 2018. https:/ / www.litbang.kemkes.go.id/laporan-riset-kesehatan-dasar-riskesdas/.

Badan Pusat Statistik. "Survei Sosial Ekonomi Nasional (SUSENAS) Kor, 2010." BPS, 2010.

https:/ / sirusa.bps.go.id/sirusa/index.php/dasar/view?kd=1558\&th=2010.

Barseli, Mufadhal, Ifdil Ifdil, and Linda Fitria. "Stress Akademik Akibat Covid-19." Jurnal Penelitian Guru Indonesia 5, no. 2 (2020).

Biro Komunikasi dan Pelayanan Masyarakat. "Peran Keluarga Dukung Kesehatan Jiwa Masyarakat." Kementerian Kesehatan RI, 2016. https://www.kemkes.go.id/article/print/16100700005/peran-keluargadukung-kesehatan-jiwa-masyarakat.html.

Creswell, John W., and J. David Creswell. “Research Design: Qualitative, Quantitative, and Mixed Methods Approaches - John W. Creswell, J. David Creswell - Google Books." SAGE Publications, Inc., 2018.

Fauzyah, Ghesya Athira Hasna'ul, Luthfi Hamdani Maula, and Iis Nurasiah. "Pengaruh Pendampingan Orang Tua Pada Pembelajaran Daring Terhadap Kecerdasan Emosional." Jurnal Pendidikan Dasar, 2020.

Jaenudin, Ahmad. “Literasi Digital Sebagai Solusi Guru Dalam Pembelajaran Era 
Digital Dan Pandemi Covid-19." Economic Education Analysis Journal 10, no. 1 (2021).

Kompas. "Ponorogo Zona Merah Covid-19, Angka Kematian Di Atas Rata-Rata Nasional." kompas.com, 2021. https://regional.kompas.com/read/2021/01/19/21172411/ponorogo-zonamerah-covid-19-angka-kematian-di-atas-rata-rata-nasional?page=all.

Kurniati, Euis, Dina Kusumanita, Nur Alfaeni, and Fitri Andriani. "Jurnal Obsesi : Jurnal Pendidikan Anak Usia Dini Analisis Peran Orang Tua Dalam Mendampingi Anak Di Masa Pandemi Covid-19." Jurnal Pendidikan Anak Usia Dini 5, no. 1 241-56. https://obsesi.or.id/index.php/obsesi/article/view/541.

Lutfiah, Siti Zakiyatul. "Persepsi Orang Tua Mengenai Pembelajaran Online Di Rumah Selama Pandemi Covid-19." Dealektik 2, no. 2 (2020).

Maercker, Andreas, and Axel Perkonigg. "Applying an International Perspective in Defining PTSD and Related Disorders: Comment on Friedman (2013)." Journal of Traumatic Stress, 2013. https://doi.org/10.1002/jts.21852.

Nurhasanah. "Peran Orang Tua Dalam Pembelajaran Daring Di Masa Pandemi Covid 19 Pada Kelompok B.5 TK Kemala Bhayangkari Bone." Educhild 2, no. 2 (2020).

Purwanto, Agus, Rudy Pramono, Masduki Asbari, Priyono Budi Santoso, Laksmi Mayesti Wijayanti, Chi Hyun Choi, and Ratna Setyowati Putri. "Studi Eksploratif Dampak Pandemi COVID-19 Terhadap Proses Pembelajaran Online Di Sekolah Dasar." EduPsyCouns: Journal of Education, Psychology and Counseling 2, no. 1 (2020).

Sari, Nidya Puspita Rachman Dwi. “Perbedaan Tingkat Kecemasan Masa Depan Karir Anak Ditinjau Dari Selfconcept Dan Persepsi Dukungan Sosial Pada Ibu Anak Tunarungu Di Smalb-B Karya Mulia Surabaya." Character: Jurnal Penelitian Psikologi. 2, no. 1 (2013). 